\title{
Rapid expansion and biodiversity impacts of the red devil cichlid (Amphilophus labiatus, Günther 1864) in Lake Sentani, Papua, Indonesia
}

\author{
HENDERITE L. OHEE ${ }^{1, \boldsymbol{v}}$, PUGUH SUJARTA ${ }^{\mathbf{1}}$, SURIANI BR. SURBAKTI ${ }^{1}$, HOLLY BARCLAY ${ }^{\mathbf{2}}$ \\ ${ }^{1}$ Department of Biology, Faculty of Mathematics and Natural Sciences, Universitas Cenderawasih. Jl. Kamp.Wolker, Waena, Jayapura 99358, Indonesia. \\ Tel./fax.: +62-967-572115, ’email: henderite.ohee@fmipa.uncen.ac.id, hohee08@gmail.com \\ ${ }^{2}$ School of Science, Monash University Malaysia. Jalan Lagoon Selatan Bandar Sunway 46150, Selangor, Malaysia
}

Manuscript received: 3 July 2018. Revision accepted: 26 October 2018.

\begin{abstract}
Ohee HL, Sujarta P, Br Surbakti S, Barclay H. 2018. Rapid expansion and biodiversity impacts of the red devil cichlid (Amphilophus labiatus, Günther 1864) in Lake Sentani, Papua, Indonesia. Biodiversitas 19: 2096-2103. The red devil cichlid (Amphilophus labiatus, Günther 1864) is one of ten exotic fish species inhabiting Lake Sentani. It is believed to be one of the most important threats to the native fish of Lake Sentani. This study aimed to document the distribution of red devil cichlids and the impacts of this species on native fish fauna. Fish were sampled in six locations in Lake Sentani using gill nets during February and March 2018. Fish species and abundance were recorded and used to calculate the relative abundance, dominance, species evenness, Shannon Wiener Index (H') and the correlation between introduced and native fish species. A total of 836 fish belonging to 12 species were recorded across Lake Sentani. Mean fish diversity $\left(\mathrm{H}^{\prime}=0.57\right)$ and evenness $(\mathrm{E}=0.25)$ were low. The red devil cichlid is the most abundant fish recorded during our surveys $(87.2 \%$ of total fish collected) and is now the most dominant fish in the lake $(\mathrm{C}=0.76)$. Moreover, it has colonized all areas sampled within the lake because of its ability to colonize new habitat and to successfully exploit a large diversity of trophic niches. However, Amphilophus labiatus was not found to be significantly correlated to native fish between different sites in Lake Sentani. The existence of endemic and native fish in Lake Sentani is now seriously threatened by the presence of the red devil cichlid throughout this lake.
\end{abstract}

Keywords: Amphilophus labiatus, conservation, freshwater, introduced species, Lake Sentani

\section{INTRODUCTION}

Lake Sentani is the biggest lowland lake in Papua and one out of 15 priority lakes in Indonesia (Ministry Environment and Forestry of Republic Indonesia 2016). The lake is located in Jayapura Regency $\left(2^{0} 33^{\prime}-2^{0} 41^{\prime} \mathrm{S}, 140^{0} 23^{\prime}\right.$ $\left.140^{0} 38^{\prime} \mathrm{E}\right), 70-90$ meters above sea level (Figure 1). Lake Sentani covers an area of approximately 9,360 ha with a watershed size of around $600 \mathrm{~km}^{2}$ and varies between $2-24$ $\mathrm{km}$ in width. The greatest recorded depth is $51.8 \mathrm{~m}$, in the western part of the lake. A total of 14 creeks flow into the lake and only one outlet, the Djafuri Stream, is located in the southern part of the lake (Puay area). The substrates of the lake consist of mud and sand, and water plants grow in shallow areas to cover $25 \%$ of the lake's surface area. Pandanus and Sago (Metroxylon sp.) grow on the shore (Umar et al. 2005; Regional Environmental Impact Management Agency of Papua Province, Research and Community Service Institute of Bandung Technology Institute 2004; Howard 1987; FAO 1972).

As a result of its high species endemism, Lake Sentani has been designated as one of the freshwater ecosystem conservation priorities in New Guinea (Allen 2007). However, the lake ecosystem has already been degraded due to habitat conversion and introduction of non-native species. Allen (1991) suggested that Lake Sentani is the most threatened freshwater ecosystem in the entire island of New Guinea due to pollution and exotic species. Water quality readings in excess of national water quality standards have been recorded in several areas of the lake, particularly in areas close to human settlements which show high readings for biological oxygen demand (BOD), chemical oxygen demand (COD), and phosphate $\left(\mathrm{PO}_{4}\right)$ (Regional Environmental Impact Management Agency of Jayapura Regency 2005, Walukow et al. 2008, Regional Environmental Impact Management Agency of Jayapura Regency 2009; Natural Resources and Environment Management Agency 2010; Ohee 2013; Purwanto et al. 2013; Indrayani et al. 2015a). Habitat alterations adjacent to the lake for restaurants and roads have to lead to increase sedimentation and reductions in water depth. The surface area of Lake Sentani is estimated to have reduced by around 100 ha as a result of this sedimentation (Indrayani et al. 2015b)

The fish community of Lake Sentani has changed significantly since surveys began during the early 1970s (FAO 1972, Subani 1978, Renyaan 1993, Umar and Safran 2006; Marine and Fisheries Department of Jayapura Regency and Research Institution of Pattimura University 2014 Renyaan (1993) reported that $50 \%$ of fish surveyed in this lake were introduced species. Recent surveys have recorded a similar proportion $52 \%$ (10 out of 19 species) are introduced, showing that fish communities in Lake Sentani are now dominated by introduced rather than native 
species (Ngamelubun 2016, Tupen et al. 2016).

The red devil cichlid (Amphilophus labiatus, Günther 1864) is a member of the Midas cichlid complex and originates from Lake Nicaragua and Lake Managua in Nicaragua, Central America. Alongside two closely related members of the Midas cichlid complex (A. citrinellus and A. zaliosus), red devil cichlids represent the largest biomass of any fish species in Nicaraguan freshwaters and are an important food source for the human population of Nicaragua (Barlow 2016, Barlow and Munsey 1976). Red devil cichlids have been introduced to several locations in Indonesia, including Kedung Ombo Reservoir in Central Java (Adjie et al. 2011), Sermo Reservoir in Kulon Progo, Yogyakarta (Ariasari et al. 2018), while Atmaja et al. (2014) recorded a sympatric species A. citrinellus in Ir. H. Juanda Reservoir, West Java.

Red devil cichlids had been introduced to Lake Sentani approximately 10 years ago. Its population has been observed to increase rapidly since it was introduced to the lake. Unfortunately, the increased population of the cichlid appears to be associated with declines of native fishes, including Sentani Goby (Glossogobius sentaniensis), Sentani Gudgeon (Oxyeleotris heterodon), two species of
Mouth Almighty (Glossamia beauforti and G. wichmanni), and the Papillate catfish (Neoarius velutinus). However, until now there has been no scientific study of the abundance and distribution of red devil cichlids in Lake Sentani and there is limited information about the extent to which this introduced species has impacted the native fishes of Lake Sentani. Therefore, this study aimed to quantify the abundance of red devil cichlid, its distribution and its impact on native fishes in Lake Sentani. The data collected in this study will also provide a baseline to evaluate the success of future management interventions aiming to control populations of introduced species and to restore the native fish communities of Lake Sentani.

\section{MATERIALS AND METHODS}

\section{Study area}

Surveys were conducted from February-March 2018 at six locations in Lake Sentani, Papua, Indonesia: Puay in the south, Ayapo and Asei in the east, Ifale and Hobong in the centre, and Yakonde in the west of the lake (Figure 1).
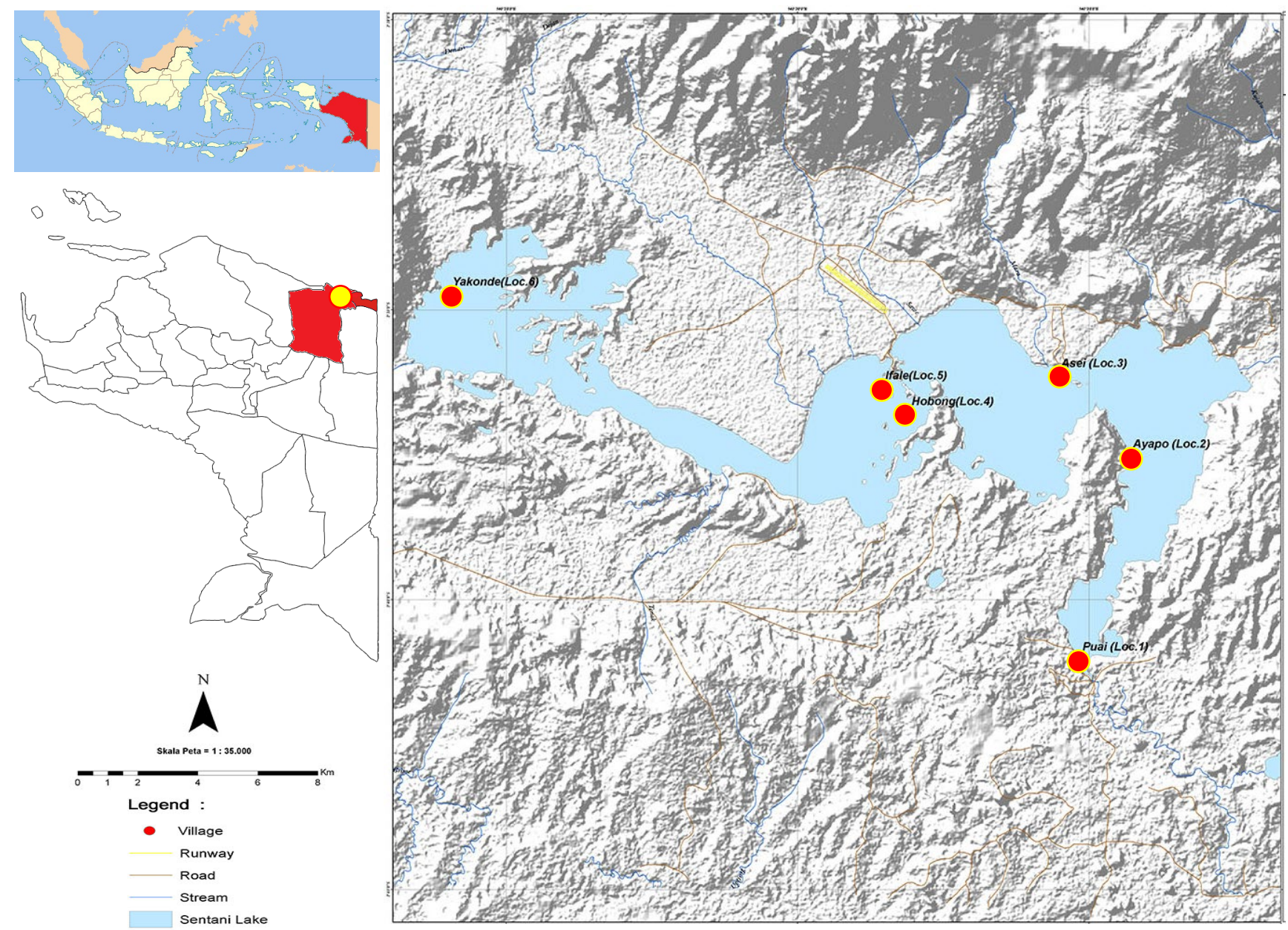

Figure 1. Six study site locations in Lake Sentani, Papua, Indonesia 


\section{Procedures}

Purposive sampling was used to collect fish. Fish were sampled with three replicates at each location, resulting in 18 fish samples across all six lake locations. Ten gill nets with two different mesh sizes (2.5in and $3 \mathrm{in})$ were combined to form one set of gill nets $(500 \mathrm{~m}$ long and $2 \mathrm{~m}$ depth) per replicate. Nets were placed at around $2-6 \mathrm{~m}$ water depth at 6.00-7.00 pm then checked the following morning between 7.00-9.00am. All fish collected during an overnight sampling period were identified to species based on Allen (1991) and Allen et al. (2000), counted and grouped into endemic, native and introduced species.

Fish species and abundance were used to calculate fish community structure including fish diversity, relative abundance, evenness, and dominance. Community structure is essentially the composition of a community, including the number of species in that community and their relative numbers. Ecological communities contain species richness or biodiversity, which are including two components, total number of species (richness) and apportionment, based on relative abundance, the distribution of individuals between species (dominance and rare species), similarity, and the functional role of the species present (Krebs 2001; Greenstreet 2003; Odum and Barret 2005).

\section{Data analysis}

Data analysis were conducted using Microsoft Excel and $\mathrm{R}$ statistical software. Shannon-Wiener Index of Diversity (H'), relative abundance (KR), dominance index (C) and evenness index (E) were calculated using Excel. The value of the Shannon diversity index (H') is usually found to fall between 1.5 and 3.5 and only rarely surpasses 4.5 (Magurran 1988). Pilou evenness (J) was used to identify evenness in each location with values ranging between 0-1. Pearson correlation coefficients were calculated to assess the relationship between the number of introduced species and the number of native species at different survey sites in Lake Sentani. Pearson correlation coefficient falls on the scale with limits -1 to +1 . The closer the value of a coefficient is to- 1 or +1 , the greater is the strength of the correlation, while the closer it is to 0 the weaker it is. Values of coefficient $r$ (positive or negative) indicate: $0.00-0.19$, a very weak correlation; 0.2-0.39, a weak correlation; $0.40-0.69$, a modest correlation; 0.70 0.89 , a strong correlation and $0.90-1.00$, a very strong correlation (Fowler et al. 1998).

\section{RESULTS AND DISCUSSIONS}

\section{The Lake Sentani}

The organisms living in Lake Sentani comprise water plants, mollusks, crustaceans, and fish. The latter three are commonly caught and sold in local markets, and consumed for their protein. Hydrilla, Elodea, Ceratophyllum, Myriophyllum, Potamogeton, and Vallisneria are some of the genera of aquatic plants found in the deeper parts of the lake, while water lilies (Nymphae), Bulrushea, and floating aquatic plants Pistis and Lemna are found in shallow areas (FAO 1972). Research Center for Limnology-LIPI (2014) recorded 11 families and 15 species of water plant in Lake Sentani as well as 20 families and 38 species of riparian vegetation. FAO (1972) recorded at least three species of crustaceans: shrimp, crayfish, and freshwater crab. Br. Surbakti (2011) recorded 11 species of mollusks (family Thiaridae), including one endemic species, Melanoides sentaniensis in Lake Sentani.

Fish communities from Lake Sentani comprise 35 species, including 10 native species (3 of which are endemic to Lake Sentani), 8 anadromous, and 17 introduced species (Ohee 2013). Chilatherina sentaniensis (Sentani Rainbowfish), Glossolepis incisus (Red Rainbowfish) (family Melanotaeniidae), and Glossogobius sentaniensis (family Gobiidae) are three endemic fishes, while Oxyeleotris heterodon, Giuris margaritaceus (family Eleotridae), Glossamia wichmanni, and G. beauforti (family Apogonidae), Neoarius velutinus, Neosilurus novaeguineae, Chilatherina fasciata (Barred Rainbowfish) are indigenous species. Pristis microdon (familiy Pristidae) and Mugil cephalus (family Mugilidae) are two out of eight species that are anadromous; that is, they are born in freshwater, but spend most of their life in marine water, before returning to freshwater to spawn. Oreochromis mossambicus, Oreochromis niloticus, Channa striata, Cyprinus carpio, and Clarias batrachus are some of the introduced fishes in the lake (Ohee 2013). Recent surveys found only 19 fish species (Ngamelubun 2016; Tupen et al. 2016), while in this survey recorded only 12 fish species. These recent surveys failed to detect several native fish species (Pristis microdon, Chilatherina sentaniensis, and Neosilurus novaeguinea) suggesting that these species may have already become extinct.

\section{The red devil cichlid in Lake Sentani}

A total of 836 fish belonging to 12 species were recorded across Lake Sentani, including eight families and 10 genera. These species include one endemic, four native and seven introduced species (Table 1). Mean fish diversity $\left(H^{\prime}=0.57\right)$ and evenness $(E=0.25)$ were low in Lake Sentani (Table 3). The red devil cichlid is the most abundant fish recorded during our surveys $(87.2 \%$ of total fish collected) and the most dominant fish in the lake $(\mathrm{C}=0.76)$ (Table 2). Red devil cichlids were in all survey locations (Table 1).

The red devil cichlid population has increased very rapidly in Lake Sentani during the 10 years since it was introduced to the lake around 2008. The introduction of exotic species into Lake Sentani has a long history beginning in the late 1930s under the Dutch government for increasing food supplies (Reeskamp 1961). During the last 10 years, more exotic species have been introduced into Lake Sentani for food by the Fishery Department of Jayapura Regency, however, these deliberate introductions have not included the red devil cichlid. Therefore, there is no information on whether the introduction of this species into Lake Sentani was deliberate or accidental. Previous fish surveys conducted in Lake Sentani during 2009-2011 
Table 1. Fish species distribution at different sites within Lake Sentani, Papua, Indonesia

\begin{tabular}{|c|c|c|c|c|c|c|c|}
\hline \multirow{2}{*}{ Family/Common Name/ } & \multirow{2}{*}{ Species } & \multicolumn{6}{|c|}{ Location } \\
\hline & & Puay & Ayapo & Asei & Hobong & Ifale & Yakonde \\
\hline \multicolumn{8}{|l|}{ Endemic } \\
\hline \multicolumn{8}{|l|}{ Eleotridae } \\
\hline Sentani Goby & Glossogobius sentaniensis & & + & + & + & + & \\
\hline \multicolumn{8}{|l|}{ Native } \\
\hline \multicolumn{8}{|l|}{ Apogonidae } \\
\hline Beaufort's Mouth Almighty & Glossamia beauforti & & & & & & + \\
\hline \multicolumn{8}{|l|}{ Ariidae } \\
\hline Papillate Catfish & Neoarius velutinus & & + & & + & + & \\
\hline \multicolumn{8}{|l|}{ Eleotridae } \\
\hline Sentani Gudgeon & Oxyeleotris heterodon & + & + & + & + & + & + \\
\hline Snakehead Gudgeon & Giuris margaritaceus & & + & + & & & \\
\hline \multicolumn{8}{|l|}{ Introduced } \\
\hline \multicolumn{8}{|l|}{ Cichlidae } \\
\hline Red devil cichlid & Amphilophus labiatus & + & + & + & + & + & + \\
\hline Midas Cichlid & Amphilophus citrinellus & & + & + & & + & + \\
\hline Mozambique Tilapi & Oreochromis mossambicus & + & & + & & + & \\
\hline Nile Tilapia & Oreochromis niloticus & & & + & & & \\
\hline \multicolumn{8}{|l|}{ Cyprinidae } \\
\hline Bonylip barb & Osteochilus vittatus & + & + & + & + & + & \\
\hline \multicolumn{8}{|l|}{ Helostomatidae } \\
\hline Kissing gourami & Helostoma temminckii & + & & & & & \\
\hline \multicolumn{8}{|l|}{ Osphronemidae } \\
\hline Snakeskin gourami & Trichopodus pectoralis & + & & & & & \\
\hline
\end{tabular}

found A. labiatus was still rare (Ohee 2013). Some of them were done by Ngamelubun (2016) and Tupen et al. (2016) that recorded high abundances of $A$. labiatus. Although the fish survey methods used by these different surveys did not allow direct comparisons of cichlid abundances between 2009 and 2018, the results of those studies demonstrate that the abundance of $A$. labiatus has increased rapidly since 2009. This study demonstrates that A. labiatus has now colonized all areas sampled within the lake, including littoral habitats at the edge of the lake and deeper areas at the centre of the lake.

This rapid expansion of red devil cichlids can be explained by the morphology of cichlids, i.e., the highly integrated pharyngeal jaw apparatus, which gives cichlids such as A. labiatus a selective advantage during the invasion and colonization of new lacustrine environments. The invading cichlids are able to successfully occupy a range of adaptive zones and to specialize progressively into diversified subzones, which may help to explain why cichlid fishes have successfully invaded new ecosystems in many different parts of the world (Liem 1973).

Mean fish diversity at each location and across Lake Sentani was low. Most locations of the lake also have low species evenness (Table 3), meaning that all locations in the lake are dominated by a small number of species at high abundance, which is mostly the cichlid, while other species have very low abundance, especially at Yakonde which is the only site located in the west of Lake Sentani. Yakonde was dominated by A. labiatus, with other species only found at very low abundance. Lake Sentani is home to three endemic fish species: Glossogobius sentaniensis) and two rainbowfish species, C. sentaniensis and Glossolepis incisus. Rainbowfish (family Melanotaeniidae) is an endemic family of fish found only on the island of New Guinea and in tropical regions of Australia (Allen 1991). The majority of endemic rainbowfish species are found in Papua, including two species within Lake Sentani (Allen 1991; Allen 1995, Tappin 2018). Rainbowfish and most native freshwater fish species of New Guinea-Australia are secondary division fishes of marine origin, which makes the fishes of New Guinea-Australia unique and different from other tropical regions, such as Asia, Africa, and South America, which tend to be dominated by primary division fishes that have evolved entirely in freshwater (Allen 1991).

Only one of Lake Sentani's three endemic fish species, Glossogobius sentaniensis, was recorded during this survey and only found at very low abundance (five individuals across the entire lake) (Table 2). The two endemic rainbowfish species were probably not recorded during this survey due to the mesh size of the gillnets being larger than the body size of the rainbowfish or because rainbowfish tend to occur in shallower water along the lake edge than the sites surveyed in this study. An additional endemic species, Chilatherina sentaniensis, which used to occur in Lake Sentani but has not been recorded in this study or in other recent surveys is assumed to be extinct in the lake. 
Table 2. Lake Sentani, Papua, Indonesia fish community parameters, which show high abundance and community dominance by the exotic red devil cichlid (Amphilophus labiatus, Günther 1864).

\begin{tabular}{|c|c|c|c|}
\hline Species & 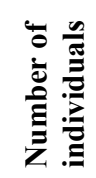 & 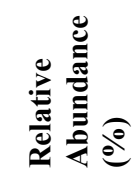 & 异 \\
\hline Amphilophus labiatus $* * *$ & 729 & 87.201 & 0.760 \\
\hline Osteochilus vittatus $* * *$ & 32 & 3.828 & 0.001 \\
\hline Oxyeleotris heterodon** & 21 & 2.512 & 0.001 \\
\hline Neoarius velutinus $* *$ & 15 & 1.794 & 0.000 \\
\hline Oreochromis mossambicus $* * *$ & 15 & 1.794 & 0.000 \\
\hline Amphilophus citrinellus ${ }^{* * *}$ & 12 & 1.435 & 0.000 \\
\hline Glossogobius sentaniensis* & 5 & 0.598 & 0.000 \\
\hline Giuris margaritaceus** & 2 & 0.239 & 0.000 \\
\hline Oreochromis niloticus ${ }^{* * *}$ & 2 & 0.239 & 0.000 \\
\hline Glossamia beauforti** & 1 & 0.120 & 0.000 \\
\hline Helostoma temminckii*** & 1 & 0.120 & 0.000 \\
\hline Trichogaster pectoralis $* * *$ & 1 & 0.120 & 0.000 \\
\hline Total & 836 & 100 & 0.763 \\
\hline
\end{tabular}

Note: ${ }^{*}$ endemic species, ${ }^{* *}$ native species, ${ }^{* * *}$ introduced species

Table 3. Shannon diversity index (H') and evenness (E) of fish in Lake Sentani, Papua, Indonesia

\begin{tabular}{lcc}
\hline Location & $\begin{array}{c}\text { Shannon diversity } \\
\text { index (H') }\end{array}$ & $\begin{array}{c}\text { Evenness } \\
(\mathbf{E})\end{array}$ \\
\hline Puay & 0.64 & 0.36 \\
Ayapo & 0.59 & 0.31 \\
Asei & 0.56 & 0.27 \\
Hobong & 0.56 & 0.35 \\
Ifale & 0.62 & 0.32 \\
Yakonde & 0.18 & 0.13 \\
Lake Sentani (average) & 0.60 & 0.24 \\
\hline
\end{tabular}

There are seven native species recorded in Lake Sentani during recent years (Ohee 2013), however only four of these native species were collected during this study (Table 2). The three remaining native fish which have previously been recorded from Lake Sentani-New Guinea tandan (Neosilurus novaeguinea), Wichmann's Mouth Almighty (Glossamia wichmanni) and Barred Rainbowfish-were not recorded in this study. Neosilurus novaeguinea has not been recorded in several recent surveys and is probably extinct in the lake, while Glossamia wichmanni has only been recorded rarely during the last 10 years. Chilatherina fasciata still occurs along lake edge but in shallower water than was surveyed in this study. The decline of $N$. novaeguinea and G. wichmanni may be due to many anthropogenic threats to the lake, including habitat alteration, pollution, and competition or predation by exotic species. Point and non-point pollutants from human activities around the lake have reduced water quality and impacted the lake's biota (Ohee 2013).

Deforestation and soil erosion have reduced water depth and lake size (Indriyani et al. 2015b). Since the stocking program of the Dutch government in late 1937, the fish community of Lake Sentani has changed to become dominated by exotic species. However, the expansion of red devil cichlids in Lake Sentani is a relatively recent change to the Lake's fauna as the species is believed to have been introduced in approximately 2008 and has only been recorded at high abundances in the lake since 2016 . Introduced fishes can have multiple negative impacts on native ecosystems, such as habitat alteration, predation, increased competition for resources, hybridization, and disease transmission (Ogutu-Ohwayo 1990; Allen 1991; Canonico et al. 2005; Dextrase and Mandrak 2006; Larsen et al. 2006; Gozlan 2008; Arismendi et al. 2009; Vitule et al. 2009; Gozlan et al. 2010; Hermoso et al. 2011). Other factors which may have contributed to the decline of native fish are an increase in the number of gillnets and reduction in the mesh size of gillnets used in the lake, linked to increases in the human population living around the lake. This change in fishing pressure has led to the increased capture of fish, including small or juvenile fish and adult females reduce recruitment. Moyle and Leidy (1992) outlined five factors which can cause aquatic biodiversity loss: 1) competition for water, 2) habitat alteration, 3) pollution, 4) introduction of exotic species, and 5) commercial exploitation. At least three of these factors are currently occurring in Lake Sentani.

\section{Impacts of the red devil cichlid on native fish in Lake Sentani}

Endemic and native species are now very rare in Lake Sentani. One endemic fish, Glossogobius sentaniensis was found to be very rare in the lake $(0.60 \%)$. Four native fish were also found to have low abundance in the lake: Oxyeleotris heterodon (2.52\%), Neoarius velutinus (1.79\%), Giuris margaritaceus (0.24\%), and Glossamia beauforti $(0.12 \%)$ (Table 2$)$. An earlier study conducted shortly after the introduction of the cichlid found that Oxyeleotris heterodon, Neoarius velutinus, and Glossamia beauforti were already rare in 2009-2011, however, Giuris margaritaceus was previously a relatively common species in Lake Sentani $(22.4 \%$ of total fish collected during 20092011) (Ohee 2013). The introduction of A. labiatus may therefore be associated with the decline of native $G$. margaritaceus if not other native and endemic species in Lake Sentani. Correlation analysis did not reveal a relationship between the red devil cichlid and endemic and native species in Lake Sentani. Two other introduced species, which are Osteochilus vittatus and Oreochromis niloticus, were found to have a significant positive correlation to two native species. Osteochilus vittatus has a strong positive correlation to Oxyeleotris heterodon $(r=0.801, p<0.05)$ and Oreochromis niloticus has a modest positive correlation to Giuris margaritaceus $(r=0.686$, $p<0.05)$. 
Table 5. Habitat characteriscs of Amphilophus labiatus and native/endemic fishes of Lake Sentani, Papua, Indonesia

\begin{tabular}{lll}
\hline Species & Habitat characteristic & Source \\
\hline Glossogobius sentaniensis & $\begin{array}{l}\text { well-vegetated lake margin on sand and mud bottoms } \\
\text { rocky and soft substrate with abundant aquatic vegetation } \\
\text { deeper still water of lakes: it is rarely encountered in the main river } \\
\text { channel }\end{array}$ & $\begin{array}{l}\text { Allen 1991 } \\
\text { Hoese andAllen (2015) } \\
\text { Allen 1991 }\end{array}$ \\
$\begin{array}{lll}\text { Large rivers and small tributaries, swamps, lakes and ponds. Turbid } \\
\text { or clear waters, usually among aquatic vegetation, to elevations of at }\end{array}$ & Allen et al. (2000) \\
Giurus margaritaceus & least 400 m & Allen et al. (2002) \\
Diurnal benthic & Allen et al. (2000) \\
Glossamia beauforti & It occurs along the vegetated margins of streams, lakes and swamps & Barluenga and Meyer (2004) \\
Amphilophus labiatus & Cichlid: It has great ability to colonize new habitats and to exploit & Liem 1973 \\
& successfully a large diversity of trophic niches &
\end{tabular}

The exact reasons for the positive correlation between native and introduced species are beyond the scope of this study, however, this correlation may indicate a shared habitat preference between the correlated species. Table 5 shows the ecological characteristics of native fish in Lake Sentani and feeding ecology of the red devil cichlids, however, the limited information on the ecology of these native species means that it is difficult to determine how the recent introduction of red devil cichlids may or may not affect native fish populations. Cichlid fishes including the red devil cichlid as well as Oreochromis niloticus have a strong ability to colonize new habitats and to exploit a large diversity of trophic niches (Liem 1973). Members of the Midas cichlid complex are known to be habitat generalists inhabiting a range of ecological niches, some of which may bring them into competition for resources with native fishes in Lake Sentani. Atmaja et al. (2014) recorded a sympatric species of Midas cichlid, A. citrinellus, has expanded to occupy most habitats in Ir. Djuanda Reservoir in West Java. Future studies on the habitat characteristics and niches of $A$. labiatus compared to native species in Lake Sentani are necessary to make stronger predictions about the impact of this introduced species on native species in the lake.

\section{Threats and conservation}

Native fish populations have been declining in Lake Sentani for at least the past 10 years. This has been reported by local communities since their daily catch is now dominated by exotic species. Currently, there is no regular species conservation program conducted by local government for Lake Sentani. Lake Sentani is designated as a priority lake in Indonesia. This prioritization is based on six categories and the categories for Lake Sentani to be designated are lake degradation: high degradation, sedimentation, pollution, eutrophication, and the decrease of water quality and quantity; and lake utilization: fishery, religious and cultural values, tourism, and others. Local government and community commitments to lake management have been categorized as 'medium level' for Lake Sentani, meaning that government and the community have not put high effort into lake management, particularly on conservation issues (Ministry of Environment and Forestry of Republic Indonesia 2016).

Lake Sentani is probably the most highly threatened of all the freshwater habitats in Papua due to its proximity to a major and growing population center (Jayapura/Sentani) and resultant human impacts such as overfishing, pollution and introduction of undesirable exotic species. However, Lake Sentani and its surrounding watershed is an aquatic biodiversity hotspot including five endemic species (Allen 2007). At this time the local government has no specific program for biodiversity and/or habitat conservation in Lake Sentani. Some existing government programs may in fact be exacerbating the current problems by expanding a programme for local people to establish fish cages stocked with exotic fish (Nile tilapia, O. niloticus). Fishery Department of Jayapura Regency has recorded more than 1,500 fish cages in Lake Sentani, around 1,300 of which are located over a limited area in the East of Lake Sentani. Moreover, some places along the lake edge have recently been developed for restaurants, settlements and road connections which places increased pressure on the lake environmet due to erosion, sedimentation, sewage etc. All these impacts pose a serious threat to the continued survival of Lake Sentani's native biodiversity. In addition to these ongoing threats from human activities, the conservation of rare endemic and native fish in Lake Sentani is now seriously threatened by the relatively recent introduction of the red devil cichlid which in only 10 years has become the dominant fish species in Lake Sentani. We recommend further studies are conducted to understand the ecology of $A$. labiatus and native fish species in order to develop a more detailed understanding of the impacts of this species and how its population can be controlled in the lake. In addition, we recommend that the multiple human threats to native and endemic species in Lake Sentani are addressed through the development and implementation of a conservation management plan for the lake and its watershed. 


\section{ACKNOWLEDGEMENTS}

The survey would not have been possible without generous financial support from Research and Community Service Directorate, Research and Technology, Higher Education Ministry of Indonesia. Special thank to head of Institute for Research and Community Services of Cenderawasih University (LPPM Uncen), Jayapura, Indonesia, Dean of Mathematics and Natural Sciences Faculty of Uncen and colleagues of Biology Department for support during research. We also thank villagers in Puay, Ayapo, Asei, Hobong, Ifale and Yakonde, who help me do fish collections. We thank students of Biology Department of Uncen, Novela Korwa and Anna Ongge, and a biology laboratory staf, Gerardinalia Ngamelubun for their help in field and laboratory.

\section{REFERENCES}

Adjie S, Utomo AD, Hidayah T, Fatah K, Aprianti S, Harmilia ED, Gautama S, Bintoro A. 2011. Bio-ecology and Fisheries Resources Potency in Kedung Ombo Reservoir, Central Java. Public Fisheries Research Center, Marine and Fisheries Research and Development Agency, Ministry of Marine Affairs and Fisheries, Palembang. [Indonesian]

Allen GR. 1991. Field Guide to the Freshwater Fishes of New Guinea. Christensen Research Institute, Madang, Papua New Guinea.

Allen GR. 1995. Rainbowfishes in Nature and in the Aquarium. TetraVerlag, Melle, Germany.

Allen GR. 2007. Fishes of Papua. In: Marshall AJ, Beehler BM (eds) The Ecology of Papua. Part one. Periplus Editions (HK) Ltd., Singapore.

Allen GR, Hortle KG, Renyaan SJ. 2000. Freshwater Fishes of the Timika Region New Guinea. PT Freeport Indonesia, Timika.

Allen GR, Ohee HL, Boli P, Bawole R, Warpur M. 2002. Fishes of the Yongsu and Dabra areas, Papua, Indonesia. In: Richards SJ, Suryadi S (eds) A Biodiversity Assessment of the Yongsu-Cyclops Mountains and the Southern Mamberamo Basin, Northern Papua, Indonesia. RAP Bulletin of Biological Assessment 25. Conservation International, Washington, DC, USA.

Ariasari A, Helmiati S, Styobudi E. 2018. Food preference of red devil (Amphilophus labiatus) in the Sermo Reservoir, Kulon Progo Regency. IOP Conferences Series: Earth and Environmental Science 139(1), $8 \mathrm{p}$

Arismendi I., Soto D, Penaluna B, Jara C, Leal C, Muñoz JL.. 2009. Aquaculture, non-native salmonid invasions and associated declines of native fishes in Northern Patagonian lakes. Freshw Biol 54: 11351147.

Atmaja P, Tampubolon RP, Rahardjo MF, Krismono. 2014. Potential invasive threat of Oscar fish (Amphilophus citrinellus) in Ir. H. Djuanda Reservoir, West Java. Widyariset (17) 3: 311-322. [Indonesian]

Barlow GW. 2016. The midas cichlid in Nicaragua. In: Thorson TB (ed) Investigations of the Ichthyofauna of Nicaraguan Lakes. University of Nebraska Press, Lincoln.

Barlow GW, Munsey JW. 1976. The red devil-midas-arrow cichlid species complex in Nicaragua. In: Thorson TB (ed.). Investigation of the Ichthyofauna of Nicaraguan Lakes. University of Nebraska Press, Lincoln.

Barluenga M, Meyer A. 2004. The Midas cichlid species complex: incipient sympatric speciation in Nicaraguan cichlid fishes? Mol Ecol 13: 2061-2076

Br. Surbakti S. 2011. Biology and Ecology of Thiaridae (Moluska: Gastropoda) in Lake Sentani Papua. Papua Biology Journal 3 (2): 5966. [Indonesian]

Canonico GC, Arthington A, Mccrary JK, Thiemes ML. 2005. The effects of introduced tilapias on native biodiversity. Aquat Conserv 15: 463483.

Dextrase AJ, Mandrak NE. 2006. Impacts of alien invasive species of freshwater fauna at risk in Canada. Biol Invasions 8: 13-24.
FAO (Food and Agriculture Organization) of the United Nations. 1972. Inland Fisheries Development in West Irian. FAO, Roma.

Fowler J, Cohen L, Jarvis P. 1998. Practical Statistics for Field Biolgy (2nd ed). John Wiley \& Sons, England.

Gozlan RE. 2008. Introduction of non-native freshwater fish: is it all bad? Fish Fish 9: 106-115.

Gozlan RE, Britton JR, Cowx I, Copp GH. 2010. Current knowledge on non-native freshwater fish introductions. J Fish Biol 76: 751-786.

Greenstreet SPR (ed.). 2003. The theory of community structure: applications in marine ecosystems. MAFCONS (Managing Fisheries to conserve groundfish and benthic invertebrate species diversity) Report 2003: 002

Hermoso V, Clavero M, Blanco-Garrido F, Prenda J. 2011. Invasive species and habitat degradation in Iberian streams: an analysis of their role in freshwater fish diversity loss. Ecoll Appl 21 (1): 175-188.

Hoese DF, Allen GR. 2015. Descriptions of three new species of Glossogobius (Teleostei: Gobiidae) from New Guinea. Zootaxa 3986 (2): 201-216

Howard KT. 1987. Inland Fisheries Development Irian Jaya. Government of the Republic of Indonesia.

Indrayani E, Nitimulyo KH, Hadisusanto S, Rustadi. 2015a. Analysis of Nitrogen, Phosphorus and Organic Carbon Content in Lake Sentani Papua Human and Environment Journal. 22 (2):217-225. [Indonesian]

Indrayani E, Nitimulyo KH, Hadisusanto S, Rustadi. 2015b. Bathymetry map of Lake Sentani, Papua. Depik 4 (3):116-120. [Indonesan]

Krebs CJ. 2001. Ecology the experimental analysis of distribution and abundance fifth edition. Benjamin Cummings, San Fransisco, USA.

Larsen BM, Sandlund OT, Berger HM, Hesthage T. 2006. Invasives, introductions and acidification: The dynamics of a stressed river fish community. Water, air, and soil pollution: Focus. doi: 10.1007/s11267-006-9073y.

Liem KF. 1973. Evolutionary strategies and morphological innovations: Cichlid pharyngeal jaws. Syst Zool 22 (4): 425-441.

Magurran AE. 1988. Ecological Diversity and Its Measurement. Princeton University Press, New Jersey.

Marine and Fisheries Department of Jayapura Regency and Pattimura University Research Institute. 2014. Potential Survey of Jayapura Regency Coastal Areas Model Development.

Ministry Environment and Forestry of Republic of Indonesia. 2016. The Grand Design of Indonesian Lake Conservation and Rehabilitation. Ministry Environment and Forestry of Republic of Indonesia, Jakarta.

Moyle, PB, Leidy RA. 1992. Loss of biodiversity in aquatic systems: evidence from fish fauna. In: Fiedler PL, Jein SK (eds) Conservation Biology: The Theory and Preservation and Management. Chapman \& Hall, New York, USA.

Natural Resources and Environment Management Agency. 2010. Water Quality of Lake Sentani Monitoring in Papua Province. Report.

Ngamelubun G. 2017. Water Quality and Fish Community Structure Relationship in Lake Sentani Jayapura. [Thesis]. Cenderawasih University, Jayapura. [Indonesia]

Odum EP and Barret GW. 2005. Fundamentals of Ecology (fifth ed). Brooks/Cole, Belmont, USA.

Ogutu-Ohwayo R. 1990. The reduction in fish species diversity in Lakes Victoria and Kyoga (East Africa) following human exploitation and introduction of non-native species. J Fish Biol 37 (A): 207-208.

Ohee HL. 2013. The Ecology of the Red Rainbowfish (Glossolepis incisus) and the Impact of Human Activities on Its Habitats in Lake Sentani, Papua. Verlag Natur \& Wissenchaft, Göttingen.

Purwanto, Suriani S, Tanjung RHR. 2013. Water Quality of Lake Sentani Study using Macrobentos Bioindicators. Papua Biology Journal 5 (2): 53-59. [Indonesian]

Reeskamp GAJr. 1961. Report on a preliminary survey of Ajamaru Lakes, Netherlans New Guinea. In: FAO (Food and Agricultural Organization of the United Nations). 1972. Inland Fishery Development in West Irian. FAO, Roma.

Regional Environmental Impact Management Agency of Jayapura Regency. 2005. Water Quality Check of Lake Sentani. [Report]. Regional Environmental Impact Management Agency of Jayapura Regency, Jayapura. [Indonesian]

Regional Environmental Impact Management Agency of Jayapura Regency. 2009. Water quality Monitoring of Lake Sentani in 2009 of Jayapura Regency. [Report]. Regional Environmental Impact Management Agency of Jayapura Regency, Jayapura. [Indonesian]

Regional Environmental Impact Management Agency of Papua Province, Research and Community Service \& Institute (LPPM) of Bandung 
Technology Institute (ITB). 2004. Final report of Lake Sentani Ecosystem Area Study, Natural Resources Control Damage Project in Border Area in Jayapura, Merauke and Jayawijaya Regencies. Regional Environmental Impact Management Agency Papua Province and Research and Community Service Institute (LPPM) of Bandung Technology Institute (ITB), Bandung. [Indonesian]

Renyaan SJ. 1993. The Freshwater fishes of Sentani Lake, Jayapura, Irian Jaya. In: Hoeft R (ed) Proceedings of the Biological Society of New Guinea, Lae. [Papua New Guinea]

Research Center fo Limnology-LIPI. 2014. Characteristics of Hydroclimatology and Determination of Inland Water Resources Status in Lake Sentani Papua. Recearch Limnology LIPI Research Center, Cibinong. [Indonesian]

Subani W. 1978. Preliminary Assessment of Sawfish (Pristis spp.) in Lake Sentani Irian Jaya. Marine Fisheries Research Institute, Jakarta. [Indonesian]

Tappin AR 2018. Home of the rainbowfish
Tupen GP, Kurnianingtyas FNR, Ohee HL. 2016. Composition of protected, prohibited and invasive fish species in Lake Sentani. Papua Journal of Development and Inovation 6 (2): 97-110. [Indonesian]

Umar C, Kartamihardja ES, Tjahyo DWH, Mujianto, Astuti LP, Sugianti Y, Widarmanto N, Romdom S, Sukandi U, Kosasih E. 2005. Annual Report on Identification and Characteristics of Habitat and Fish Populations in Lake Sentani, Papua Province. Marine and Fisheries Research Agency, Ministry of Marine Affairs and Fisheries, Jakarta. [Indonesian]

Umar C, Safran M. 2006. Composition of species and fish catches in Lake Sentani, Papua. Biodiversitas 7 (4): 349-353.

Vitule, JRS, Freire CA, Simberloff D. 2009. Introduction of non-native freshwater fish can certainly be bad. Fish Fish 10: 98-108.

Walukow AF, Setiyanto DD, Kholip, Soedharma D. 2008. Analysis of pollution Load and Assimilation Capacity of Lake Sentani, Papua as an Effort to Conserve Aquatic Environment. Biol News 9 (3): 229. 236.

http://rainbowfish.angfaqld.org.au 